\title{
Modernised Traditional Lime Plasters for Modern Historic Living of Built Heritage: Case Studies from Germany and Reflection for China
}

\author{
Tanja Dettmering
}

August-Bebel-Schule, Berufliche Schule des Kreises Offenbach am Main, Germany

Email: tanja.dettmering@arcor.de

\begin{abstract}
Traditional plasters were generally produced until about the middle of the $20^{\text {th }}$ century. Among traditional plasters, lime plaster in Europe occupies a position of outstanding importance. Plasters play a key role as a protective and decorative outer layer in the care and rehabilitation of the built heritage. To meet the needs for protecting masonry and living in historic buildings in the modern age, traditional lime plasters can be modified to fulfill technical and aesthetic functions. This paper makes an assessment of the use of traditional and modern lime plasters in Germany. The rediscovery of lime plaster as a material for use in cultural heritage conservation has led to the application of traditional and modern plasters along with advanced guidelines and standards for their production and application. In China, a kind of lime-system has recently been developed that is historically and technically compatible with the types used historically; the new types lend itself well to use in modern conservation.
\end{abstract}

KEYWORDS traditional plaster, lime, built heritage, modern living in historic structures

Received February 10, 2019; accepted March 20, 2019.

\section{Introduction: Building Lime and Lime Plasters}

In general, traditional plasters are understood as signifying those produced until about the time of the introduction of synthetic resin and silicone resin plasters, i.e., around the early 1950s (Dettmering and Kollmann 2011). Among traditional plasters, lime plaster is of outstanding importance. Through modern scientific analytic and testing technologies, two types of building lime have been identified: air lime and lime with hydraulic properties.

European and Chinese research has found that natural hydraulic lime has greater merits than other old material applications, such as stone masonry, in terms of workability, compatibility, and durability. Historically, natural hydraulic lime has been found to be more chemically and mechanically compatible when used in constructions with other materials (Dettmering 1997; Dai 2018).

Roman lime kilns, dating from around $200 \mathrm{BC}$, have been discovered in Germany at Bad Münstereifel. In ancient Rome, Vitruvius was the most important author about its architecture; his famous work, De Architectura libri decem (dating from about 35-25 BC), first appeared in German translation in 1548. It contains detailed descriptions of the application of lime mortar techniques, and it exerted a great influence on all Occidental architecture (Vitruvius 1987).

Until the $18^{\text {th }}$ century, however, the use of hydraulic lime mortar set under water is documented exclusively in a hydraulically reacting context, such as with trass or brick splitting: it was used as a kind of 'Roman cement'. Natural hydraulic lime mortar has been produced from marl (without additives) since ancient times. Smeaton's publication in 1791 spurred the search for clayey limestone, and the result in 1796 was the patent by James Parker for what became known as Parker cement (Quietmeyer 1911). Subsequently, mortar materials called 'Roman Lime' and 'Roman Cement' emerged: they burned at higher temperatures than water lime. Until after 1830, Roman Cement was sold to France, the United States, and Germany. With the rise of the lime mortar and cement industry in the late $19^{\text {th }}$ century, numerous factories were built to produce and process binders, and descriptions of suitable deposits appeared. Descriptions about the production and use of hydraulic lime and results of analyses of historically used 
mortars indicate that natural hydraulic lime was often used in the past.

Until the early $20^{\text {th }}$ century, lime plaster was employed as a protective outer and inner surface on buildings. Following the development of cement technology in the second half of the $19^{\text {th }}$ century, plaster with lower calcium content became increasingly utilised. From analyses of historical plasters, the binders generally consisted of predominantly carbonic hardening air limestone, which was mostly applied in several layers and frequently had to be refurbished. In addition to pozzolana and brick dust, plaster also contained organic additives, such as animal protein, casein, and blood, to provide greater durability (Rauschenbach 1994). Owing to the availability of local limestone, the binders of historical plasters often relied on natural hydraulic limestone, whose setting behaviour is based on both carbonate and hydraulic hardening (Dettmering 1997). According to German standard DIN 18550 (DIN 2018), lime plaster is classified as mortar along with air-hardening lime and hydraulic lime. All those types can be used as both sub-plasters and upper plasters. However, there is no clear definition of the term 'lime plaster'. That is due to the fact that lime plaster can be composed very differently as a result of the chemical and mineralogical range of the raw material: lime.

The hardening properties of lime plaster are significantly influenced by the binder with respect to the aggregate ratio, type of aggregate used, prevailing conditions for the structure, and design technique. In addition, the binder used in the mortar formulation plays a key role. Regarding protection against rainfall, 'classic' lime plaster is not water repellent: the water absorption coefficient is $>2.0 \mathrm{~kg} /(\mathrm{m} 2 . \sqrt{\mathrm{h}})$ and is accordingly classified as absorbent. However, older multilayered plastering has certainly worked for centuries: if the layer thickness is sufficient, capillary resistance layers result (Worch 2016). In historic buildings, which have mostly thick walls and thick layers of plaster, protection against rainfall was not so important. Heavy rainfall could be accommodated and subsequently discharged owing to the high storage capacity of the masonry (Dettmering, forthcoming). Today, however, as a result of the long-time action of moisture and pollutant elements in rainwater, damage to plaster is on the rise. The protection of plaster surfaces against capillary water absorption is achieved using either organic additives (such as natural organic resins employed over centuries) or water-repellent paints and impregnating agents, which have been utilised since the $19^{\text {th }}$ century. The effectiveness and durability of plaster surfaces has to be considered with regard to the possible damage by moisture.

\section{Ecological Aspects of Traditional Lime Plaster}

In Germany and China, there is increasing awareness of the necessity to preserve and manage cultural and historic buildings. In line with recognition of the need to maintain sustainable development of the built heritage as a central task of urban and regional development using natural products, lime-based plaster offers considerable advantages: it does so ecologically and is suitable in terms of raw material costs and life-cycle assessment. Lime is considered environment friendly: it is recyclable, helpful in climate regulation, offers energy-saving benefits, and has advantages for human health, as detailed below.

From an ecological perspective, hardened lime plaster on a wall is effectively a 'starting material'. Reference is frequently made to the 'lime cycle'. With that cycle, lime plaster is made by initially burning limestone. Thereafter, slaking results in $\mathrm{CaCO}_{3}$, which absorbs carbon dioxide and produces water vapour. Lime plaster usually has high vapor diffusion resistance and absorption; thus, it allows moisture to be easily absorbed and released. Through its high alkalinity, lime has a recognised antibacterial effect.

A prime concern with historic sites concerns the choice of restoration, renewal, or preservation as the most appropriate action. When preserving such sites, it is necessary to restrict repairs to an absolute minimum. With regard to sustainable repairs to the structures in question (including modernisation for the purposes of revaluation, considerations of the structure's long-term usability, and preservation repairs), all actors should strive for solutions that are compatible with the character of the building. To maintain a high level of usability of the structure-while accommodating the demands of modern residential comforts-it may be necessary to slow or halt repair efforts.

The case studies described in the following sections address object-specific solutions: in those cases, it was necessary to find precisely defined plaster properties in accordance with the various structures' requirements. To that end, combinations of building-site and ready-mixed mortars were used. It should be noted that such longmonitored structures serve as good examples for the kind of holistic approach that should be adopted in contemporary conservation in accordance with international methodically applied standards.

\section{Modern Use of Lime Plaster: Case Studies from Germany}

Here, we make a detailed assessment of the use of plaster materials and treatments in preventive conservation and 

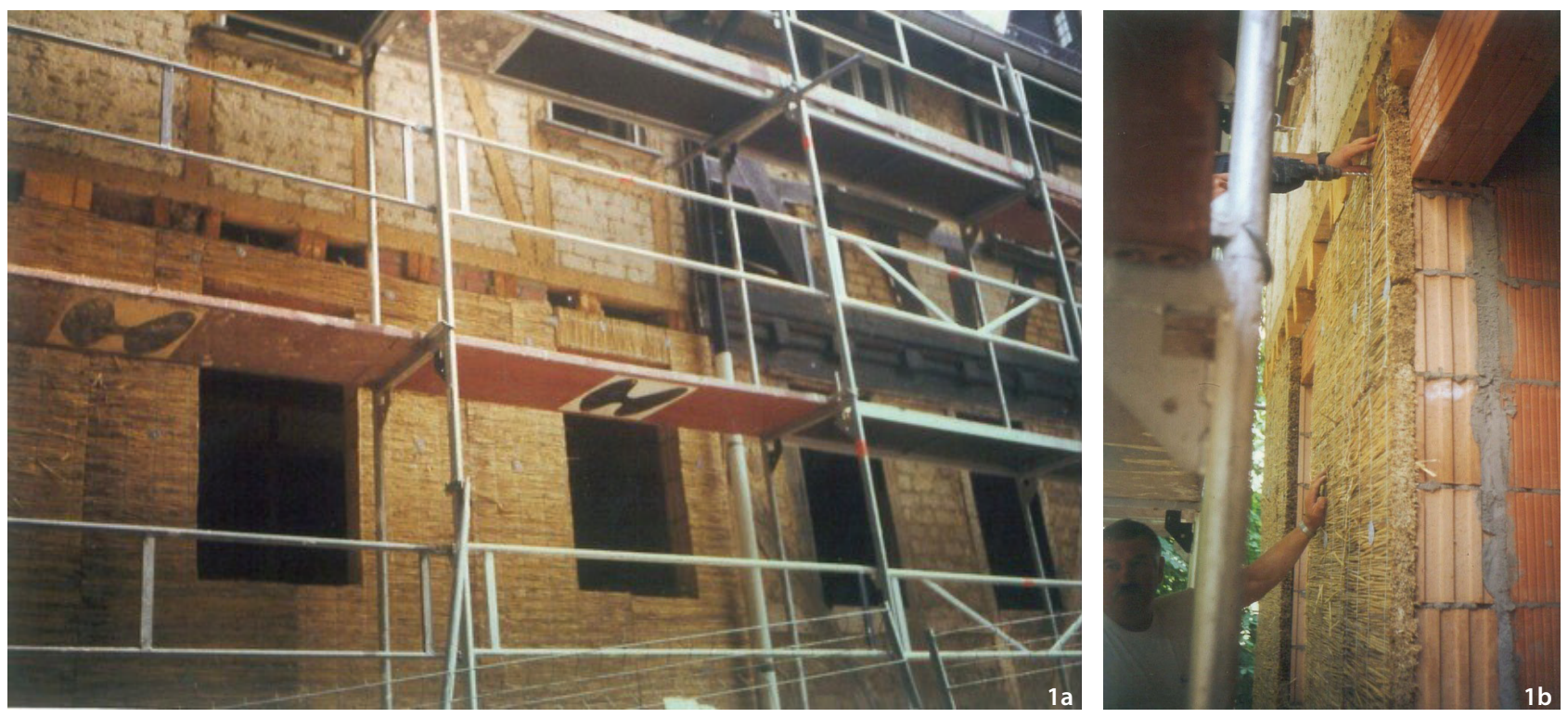

Figure 1 Reed insulation was installed during the restoration of the 'Lottehaus' in Wetzlar, Germany (Source: the author).

management. When conserving and preserving historic buildings - in addition to quality and aesthetics-the type of plaster employed is an important consideration. Making such an assessment requires specialist knowledge. Maintaining old buildings demands sophisticated conservation measures. To meet client' requirements for appropriate, long-term conservation necessitates close cooperation among assessors, planners, contractors, and material suppliers.

When undertaking the conservation and preservation of historical buildings, it is necessary to consider the plaster base and identify the structure's specific and general requirements. From an economic and historical viewpoint, it is important to find solutions that achieve the best fit for the building's basic value and measures for renewing or preserving its plaster. As part of that process, areas of damage to the plaster should be identified, and appropriate methods for dealing with those problems have to be detailed.

In Germany, plaster was traditionally expected to have the following properties to be indicated: water absorption; conductivity; fire resistance; permeability to water vapor; high tensile adhesion strength. If a recipe should be adjusted as faithfully as possible, at first laboratory analyses are required. When restoration of plaster is undertaken in Germany, both ready-mixed mortar products and mixtures created at the site are employed. However, in commercial upgrading, ready-mixed plaster mortars tend to be more commonly used.

\section{Lottehaus in Wetzlar, Hesse, Germany, $17^{\text {th }}$ Century}

Built in 1653 and reconstructed in 1750-1754, the Lottehaus serves as a museum for Johann Wolfgang von
Goethe. Since 1774, it has been a collection point for important value issues. The building underwent considerable restoration in 1999, the $250^{\text {th }}$ anniversary of Goethe's birth. The Lottehaus is a half-timbered building, though little of the original structure remains following a bomb blast in World War II. The building was reconstructed in 1949 (Dettmering and Kollmann 2011). The bomb resulted in considerable damage to the framework and overall structure as well as to all surfaces and floors. For the anniversary, careful restoration was undertaken, particularly with room settings, in 1998-1999. The materials used in the restoration included clay, reed to provide thermal insulation, and various lime plaster systems. At that time, old colour schemes used in the interior were discovered, some behind old layers of wallpaper and modern gypsum plaster. The individuals undertaking the restoration carefully examined and documented such findings (Dettmering and Kollmann 2011). In the restoration work, existing clay plaster was integrated with new ready-mixed clay mortars. After interim storage, the existing clay plaster was soaked and mixed with the new ready-mixed clay plaster before being applied. Some structural elements were rebuilt using porous brickstones. Owing to the very high absorbency of the brickstones, they first had to be thoroughly wetted before use.

For the restoration, air lime mortar was mainly used in the interior as a finishing coat for ceilings; it was also used outdoors on clay, natural stone masonry, and on reed beds. The lime plaster consisted of lime and natural hydraulic lime mortar in the ratio of $3: 1$, which corresponded to a compressive strength index of about $2 \mathrm{MPa}$ after 28 days. 

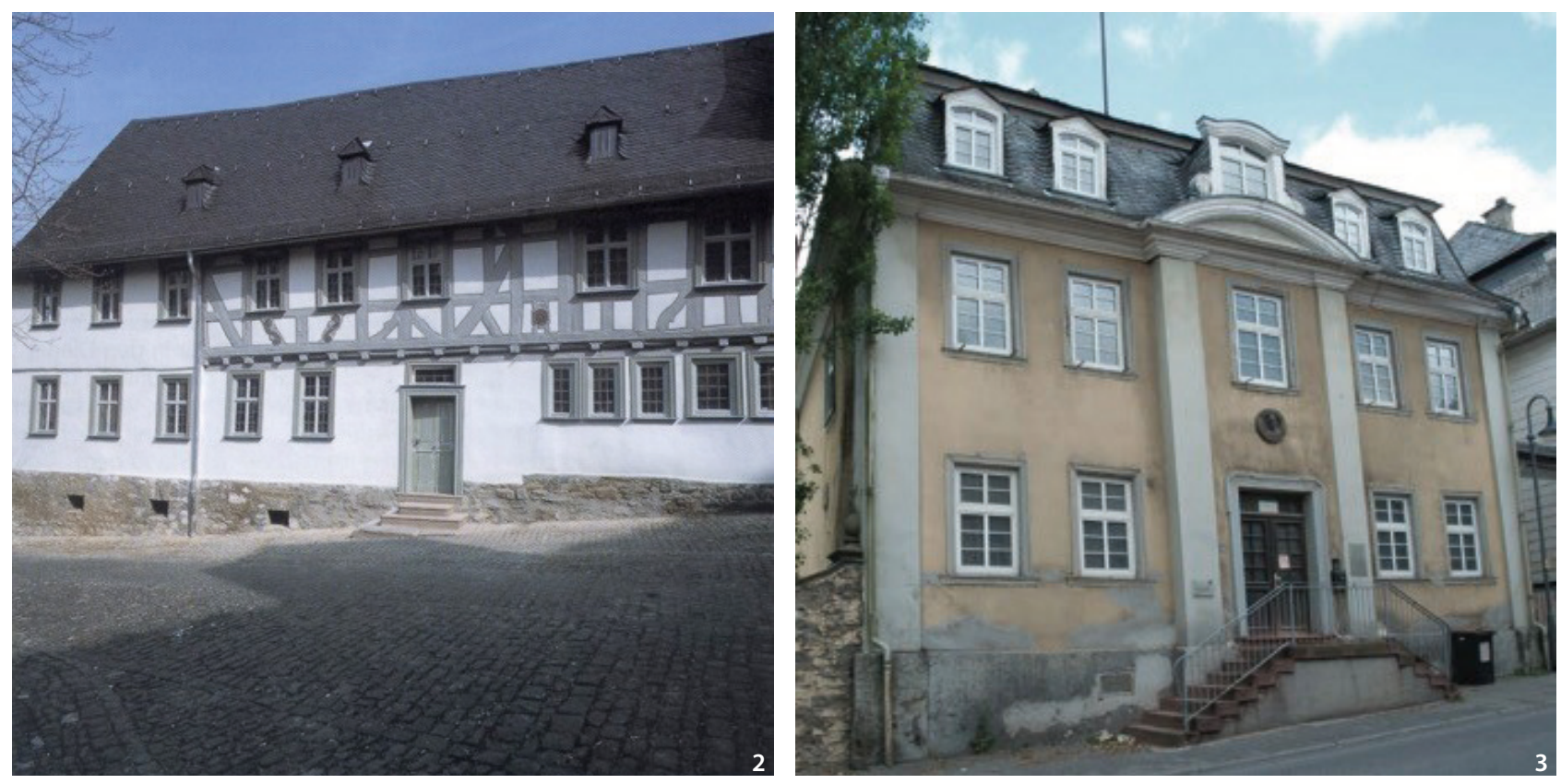

Figure 220 years after restoration, the Lottehaus in Wetzlar received the Hessian Monument Protection Award (Source: the author). Figure 3 Usingen fürstliches Beamtenhaus before restoration (Source: the author).

The thickness of the reed insulation panels was in the range of 2-5 cm (Figure 1). Insulation lime mortar, with a grain size of $4 \mathrm{~mm}$, was applied over large areas of the reed insulation panels. Subsequently, a top coat of lime mortar, with a grain size of $2 \mathrm{~mm}$, was applied. When the Lottehaus was originally constructed, the half-timbering on the upper floor was visible, but that became plastered over in 1750

Following the restoration of the Lottehaus, the halftimbering became visible once again, and stone-gray paint was applied to the woodwork. The infill within the halftimbering was plastered using clay with lime plaster to protect it from the elements. When restoring the Lottehaus, consideration had to be made about regulating the temperature and humidity in the structure. That involved conflicting requirements. On the one hand, with historic buildings, it is usual practice to minimise humidity and temperature control. On the other hand, preservation of the valuable exhibits in the Lottehaus called for an environment of high humidity and constant temperature. For museum visitors and staff, the interior temperature and humidity had to be at comfortable levels. It was decided that the best solution would be to use convection heating with humidity control in conjunction with wall heating built into the clay plaster. The temperature-controlled wall heating prevented condensation damage caused by high humidity levels in the stone masonry. On the basis of investigations into the rebuilt structure of around 1750, it was decided to paint the infill in shades of gray and ocher.
To reflect how the interior originally appeared, parts of an old mural were integrated into the new plaster on the ground floor. In the so-called State Room on the upper floor of the Lottehaus, decorative paintings feature antique vases and statues of Greek gods in accordance with the popularity of Greek elements with the Rococo style. As a result of the extensive interior and exterior restoration work over 20 years ago, the Lottehaus received the Hessian Monument Protection Award (Dettmering and Kollmann 2011) (Figure 2).

\section{Restoring a Plastered Framework Structure}

The Usingen fürstliches Beamtenhaus (Princely Civil Servant House) was built in 1733-1734. The structure is of great architectural significance and is located in the residential city of Usingen, which is in the rural upland Taunus region near Frankfurt (Figure 3) (Trommer 2016). The building is very close to the Hessenpark Open Air Museum.

According to Germany's cultural heritage classification for buildings as works of art and for urban planning reasons, the fürstliches Beamtenhaus is listed as an architectural monument. The building features half-timbered stud walls and a quarry stone base. In the 1950s, it had plastering on a metal reinforcement: cement upon metal wire upon plaster (Figure 4). A purely mineral lime insulation plaster outside and within was applied to allow energyefficient use of the structure as a residential house. 


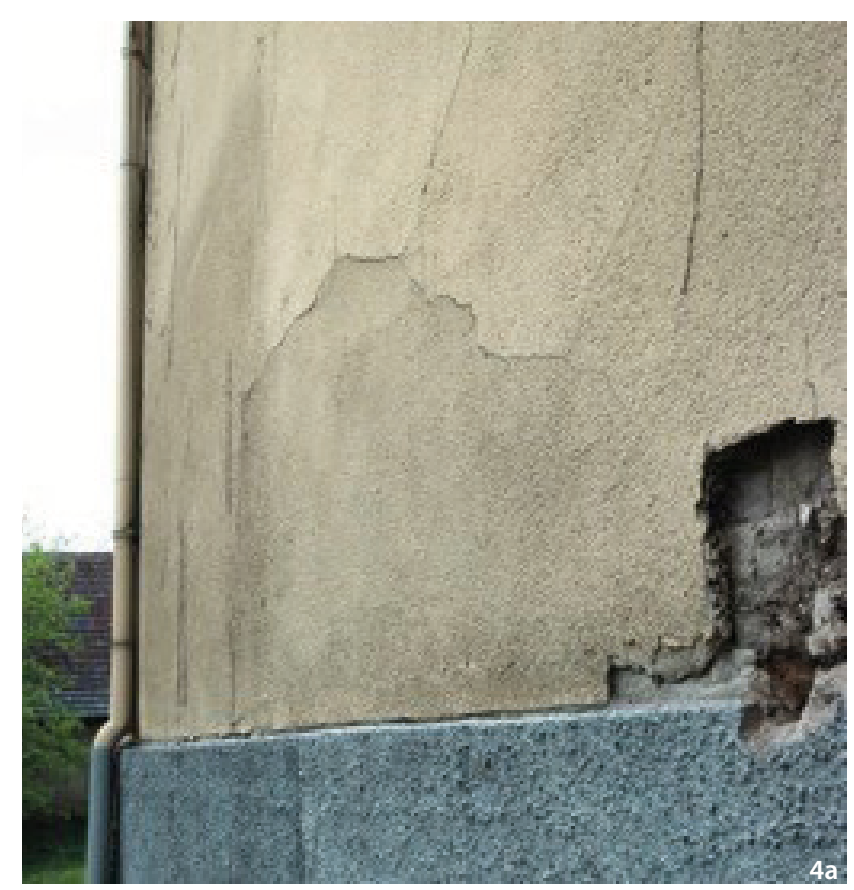

Figure 4 Cement plaster applied in the 1950's. (Source: the author).

The fürstliches Beamtenhaus has two floors. It was built using a plaster framework, and it has a three- to five-axis structure on its main façade (street side). The façade is enclosed by pilasters with a central risalit. The strong design of the building is emphasised by its main axis with a central risalit, a two-flight staircase, and an entrance portal with a Baroque profile.

It was decided that the plaster in the façades required basic restoration. That work involved completely removing the plaster surface that had been applied in the 1950s (Figure 4).

The decision to undertake the restoration work was based on an assessment of the plaster in the upper parts of the building. It was concluded that the most compatible approach for the monument would be to use a pure natural lime plaster. Owing to its appropriate degree of hardness, a stable natural hydraulic lime was chosen for the base of the building. For this work, a great range of historical plasters and frame settings was available, but the guiding concept in restoring the architectural surfaces was on maximum conservation. It was necessary to undertake the work in an appropriate manner with respect to the historic clay and lime plaster systems. A suitable colour system was applied using a mineral colour system (Trommer 2016).

For the restoration work, it was decided that using a plaster with natural hydraulic lime mortar as a binder and mineral lightweight aggregate would offer optimal thermal insulation and be in accordance with the needs of

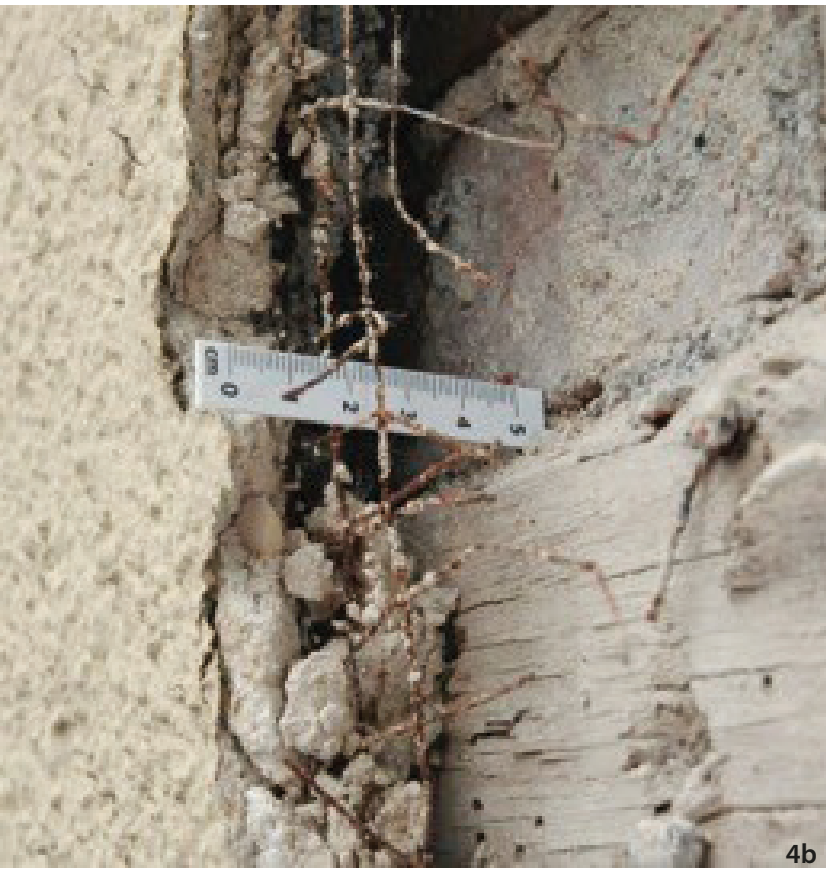

modern living (Figure 5). The lime plaster applied to the building for thermal insulation was a factory mix with low compressive strength: the compressive strength after 28 days was 0.4-2.5 MPa.

\section{Former Monastery Church Spieskappel (North Hesse, Germany), $12^{\text {th }}$ Century}

The monastery church Spieskappel was built in 11751225 , and its masonry consists mainly of basaltic lapilli tuff. That tuff is brittle, but it is famous because of its use in the structures of Wilhelmshöhe in Kassel. Wilhelmshöhe, a mountain park that is a UNESCO World Heritage site, was built in the early $18^{\text {th }}$ century and is an example of Germany's absolutist architecture. Investigations at Spieskappel have determined that the church was plastered until the $17^{\text {th }}$ century, and 22 different types of mortar could be identified (Dettmering 1997).

At Spieskappel, loss of the exterior plaster left the natural stone masonry without protection from the weather; accordingly, the masonry began showing considerable damage (Figure 6). That resulted in high susceptibility to changes in moisture, which led to swelling and shrinkage within the masonry. The result was structural disorders, cracks, and expansion zones in the masonry and detachment of up to $10 \mathrm{~cm}$. Thus, it was decided that preservation and restoration of the tuff masonry would have to be undertaken. In particular, the concept of a 'sacrificial plaster', which would serve as a protective layer for the stone, was adopted. 

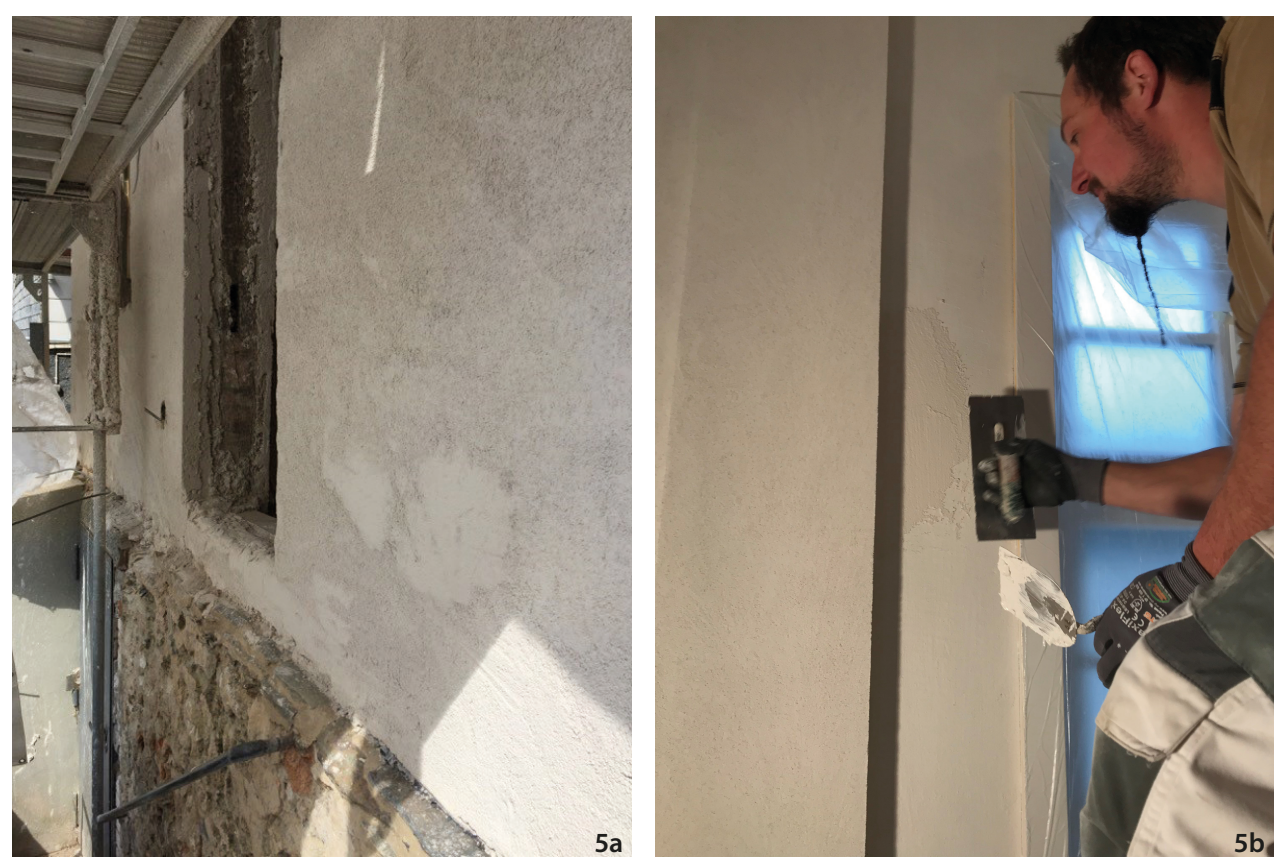

Figure 5 Ongoing restoration work with modernised lime insulation plaster in 2018 accompanied by inspections and planned to be monitored by experts (Source: the author).

Figure 6a Heavily weathered tufa with mortar residues (Source: the author).

Figure $6 \mathbf{b}$ Macroscopic image of a tufa stone (predominantly basalt, embedded in a clayey, smectitic matrix (Source: the author).
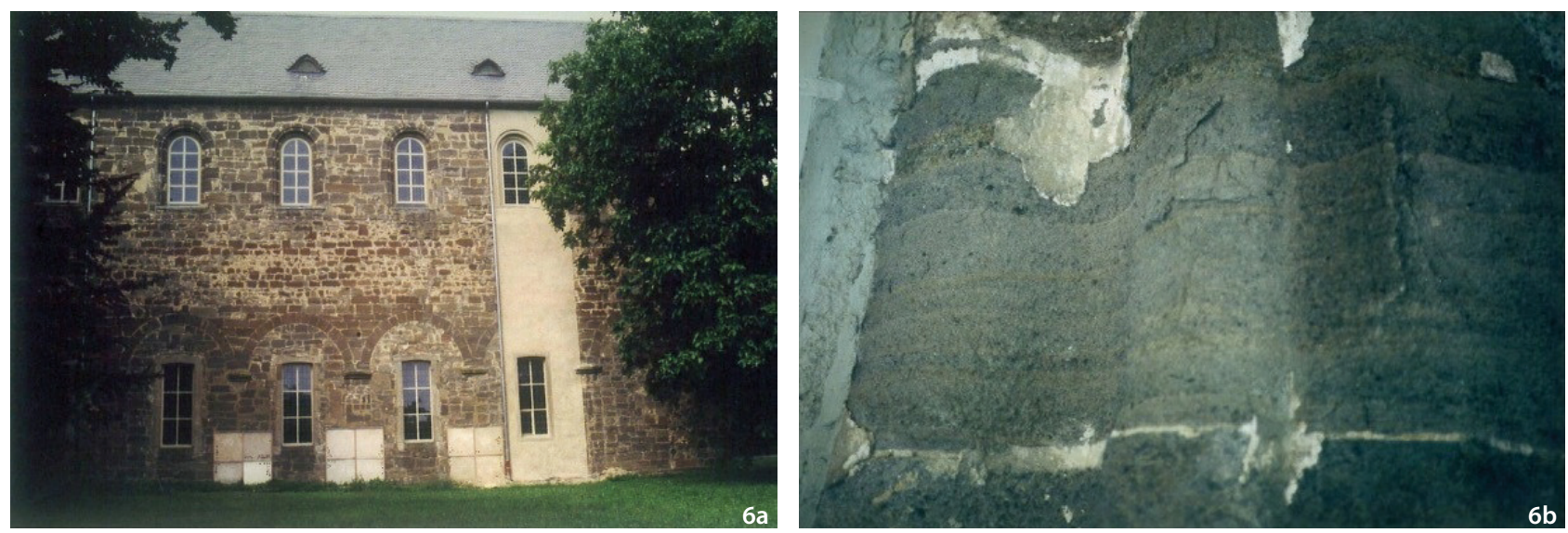

When developing the plaster for the restoration work at Spieskappel, the characteristics of the stone used for the masonry-notably the very low compressive strengths (about $8.8 \mathrm{~N} / \mathrm{mm}^{2}$ on average) and moduli of elasticity (7.2 $\mathrm{N} / \mathrm{mm}^{2}$ ) - had to be considered. For low frost resistance, the high porosity and water absorption coefficients $(9.8$ $\mathrm{kg} / \mathrm{m}^{2} \cdot \mathrm{h}^{1 / 2}$ on average) also had to be taken into account.

On the basis of sample surfaces and laboratory determinations and comparisons, plasters with natural hydraulic and high-hydraulic limes in addition to various regional sands were used to fulfill the technical criteria in three cases at Spieskappel. After consideration of weathering processes (including frost effects) that would lead to swelling and shrinkage, it was decided that a soft plaster should be used for the monastery church. Those undertaking the restoration work concluded that the points where moisture could enter the tuff could be reduced but that it was not possible to dry the stone: if they did so, the plaster and upper stone layer would be compromised. Following preliminary results, a plan for applying areas of various lime plasters was drawn in 1994 and subjected to further evaluation.

Following five years of investigation at Spieskappel, experts decided that the best course would be to conduct restoration using a natural plaster made of natural hydraulic lime and locally available coloured sand. The restorative plastering took place in 1998-1999. The previous appearance of the church with its stone facing was intentionally changed (Figure 6, Figure 7). Above the arched lower-middle windows on the southern facade, a 'window to history' was created, which offered a view of the original, underlying tuff and plaster. That window also offered a possibility of monitoring the condition of underlying stone.

Before the measurement, the differently coloured tuff lent a vivid aspect to the southern façade of Spieskappel; that impact has today been lost as a result of the uniform appearance. If large façades need to be designed with 

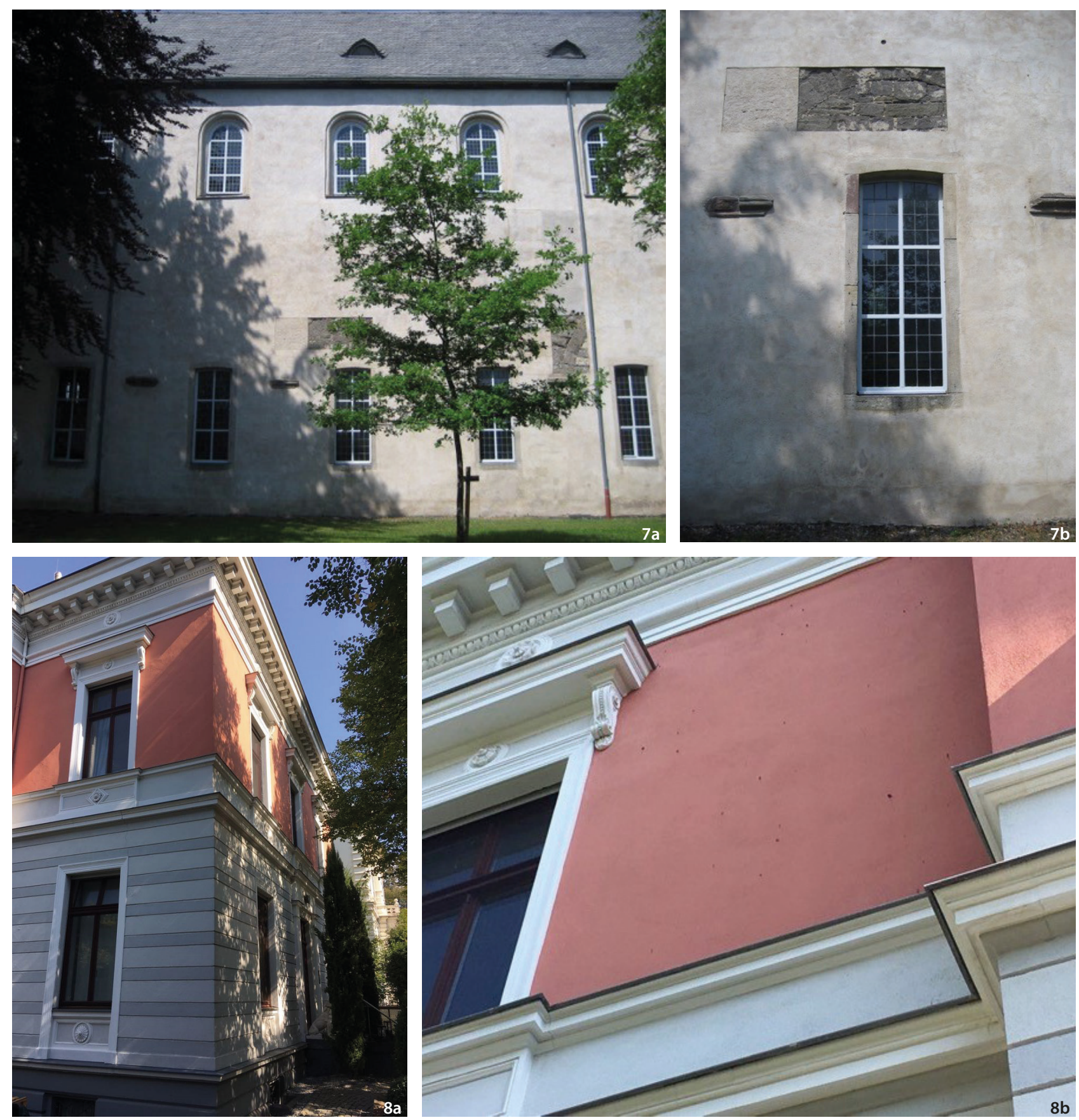

Figure 7a South façade, one decade after the application of the sacrificial lime mortar based on natural hydraulic lime (Source: the author). Figure 7b The 'window to history' (Source: the author).

Figure 8 Pictures of Classicist Villa, Park Street, Wiesbaden, Germany, in 2018; 20 years after restoration with lime plaster and red-coloured lime paints (Source: the author).

natural plaster, a stronger impact can be created using coloured aggregates, plaster structures, or more impressive architectural orders.

Today, 20 years after the restoration work at Spieskappel, the specially developed natural plaster still effectively works as a protective layer for the delicate tuff. In 2017, the sacrificial plaster itself received a protective coat of a lime-based paint.

\section{Classicist Villa in Wiesbaden, Hessian State Capi- tal, Germany (about 1870)}

In Germany, the Classicist Villa in Wiesbaden is typical of country houses. In the $19^{\text {th }}$ century, Wiesbaden gained importance as a residential city and spa. At that time, halftimbered houses tended to be regarded as constructions for poorer people, and so half-timbering was frequently hidden beneath plaster. Wealthier individuals had villas 


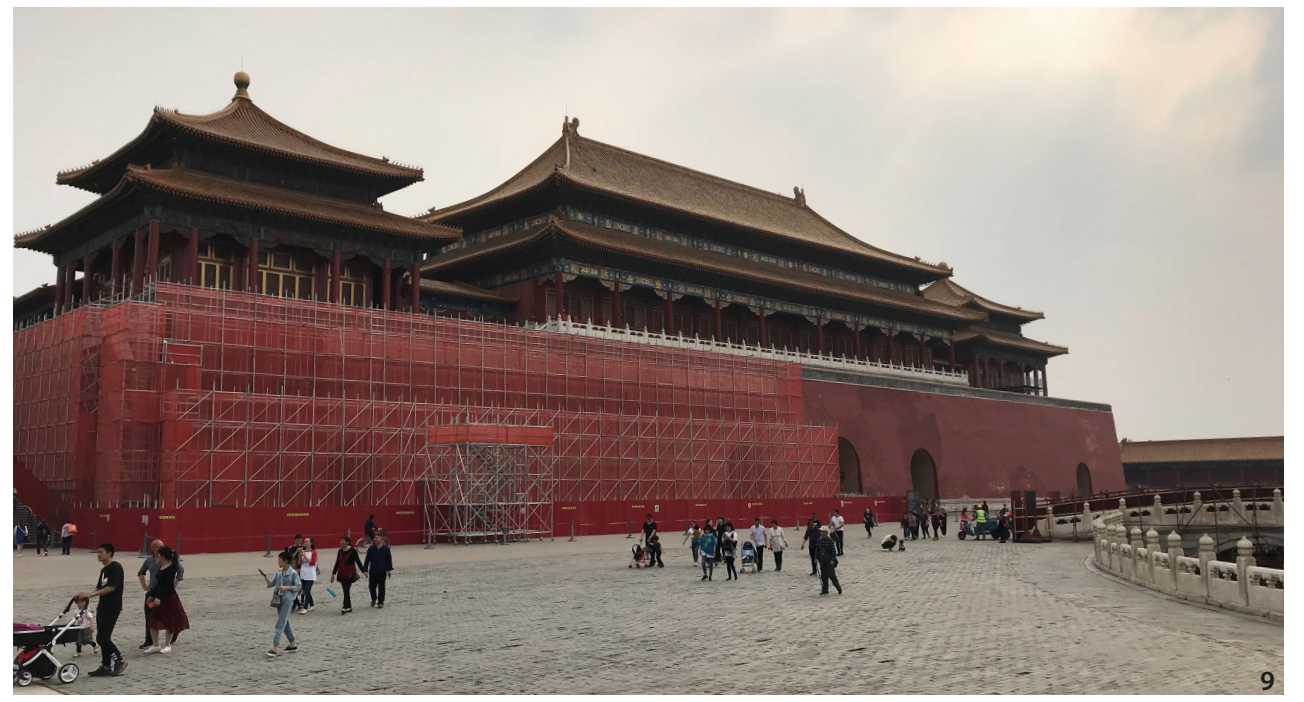

Figure 9 Lime plaster maintenance for Wu Men (Meridian Gate) of the Palace Museum in Beijing during the summer 2018 (Source: the author). constructed in brickwork, which were plastered; occasionally the plaster imitated a bossing stone structure to lend an appearance of grandeur.

20 years ago, plaster over the entire façade of the Classicist Villa was visibly detached. There was clearly a lack of adhesion of the painted top coat, which had a thickness of $0.5-1 \mathrm{~cm}$; that was above soft lime mortar, which had a thickness of about $2 \mathrm{~cm}$. The underlying masonry was brickwork covered with lime mortar.

Following preliminary examinations and tests, restoration was undertaken. The efforts were successful, and the Classicist Villa is now in good condition. The entire exterior façade, including the base area, was re-plastered using a lime plaster and then painted with a lime-based paint to match the lime mortar. The new pink lime-based paint has helped preserve the building (Figure 8).

\section{Considerations for China}

China has a considerable amount of architectural heritage, and it has to deal with many challenges related to preservation (Figure 9). However, China was somewhat slow in recognising the need to undertake preservation efforts.

Over the past 10 years, the Tongji Architectural Conservation Laboratory has conducted numerous research projects and case studies. It has developed guidelines that apply international conservation standards, which have been adapted to Chinese sites and building materials (Dai and Schwantes 2016).

Since 2008, some governmental and nongovernmental research projects have been initiated in China in conjunction with Tongji University, other universities, and such associations as the International Association for Science and Technology of Building Maintenance and Monument Preservation (WTA 2002, 2006, 2018). Those collaborative research projects focus on four special areas: (1) understanding traditional lime plaster techniques by studying preserved architecture; (2) developing technologies to conserve or restore historical plasters; (3) revitalising the use of traditional lime plaster for ecological restoration and sustainable construction; and (4) reviving traditions for using lime plaster in buildings and organising workshops and training for architects and practitioners.

From the results of joint investigations, it has been found that at least some parts of the Great Wall of China, built in the Ming Dynasty, were constructed using dolomitic lime (Figure 10). That kind of lime is not very durable-especially in the industrial climate of the modern age (IFS 2003). Scientific studies of dolomitic lime have helped clarify why the Great Wall has suffered severe damage in recent decades owing to the increase in industrial $\mathrm{SO}_{2}$ and $\mathrm{NO}_{\mathrm{x}}$ emissions. Conserving such an architectural heritage is a matter of particular concern.

Building lime produced from burned oyster shells was already in use in China in 771 BC. Two slaking techniques for quicklime for use in constructing and decorating buildings were described in 1061 (Song Dynasty). In China, there is also a long tradition of using decorative lime plasters (Figure 11). However, the formulation and durability of those plasters demands scientific analysis.

In a historic urban landscape, traditional plasters are character-defining architectural elements. Conservation redevelopment of Enning Road in Guangzhou began in 2018. Using building archeological and documentation methods, a German-Chinese group studied the road's historical plasters (Figure 12). This kind of 

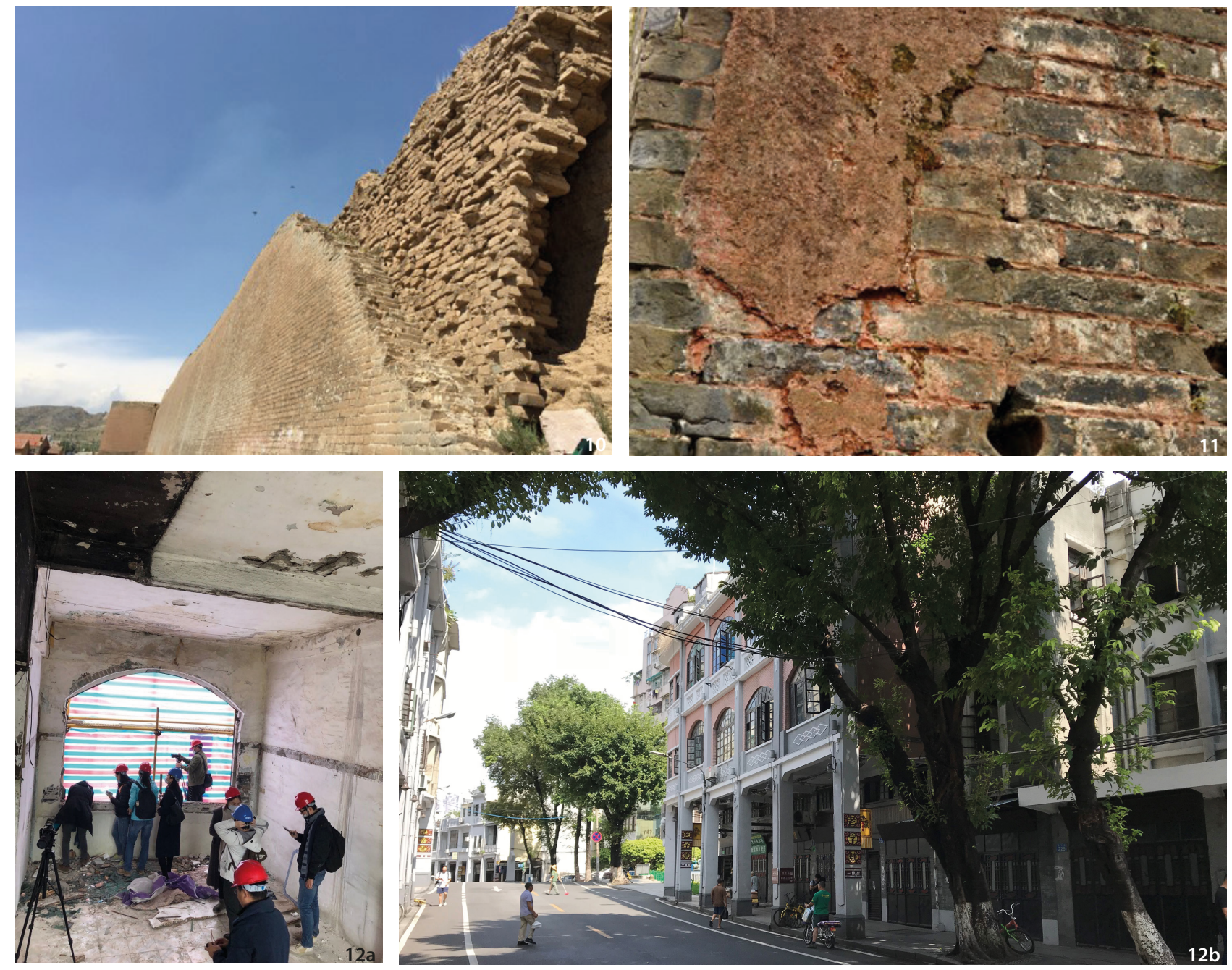

Figure 10 Ruins of the Great Wall in Zhangjiakou, Hebei Province, constructed with dolomitic lime (Source: the author). Figure 11 Historical lime plaster in China: decorative plaster from 1413, Ming Dynasty in Nanjing (Source: the author).

Figure 12 Documentation of building archaeological work to reveal historic plastering technique during the redevelopment of Enning Road in Guangzhou in January 2019 (Source: the author).

documentation and replication of traditional plasters will help restore the historical environment with greater authenticity and integrity.

Revitalising the use of traditional materials and building techniques for renovation or for application in modern constructions involves challenges. The defects observed in one building used as a kindergarten in Hangzhou show that conventional cement plaster does not work when used with masonry contaminated with salts under conditions of extreme humidity (Figure 13). To deal with this situation, a new plaster system based on functional rendering using lime plaster and lime wash is being developed under the Elite Innovation Program (2015) of Huzhou Municipal Government, Zhejiang Province of China.

In both rural and highly developed urban regions, the lack of knowledge concerning traditional materials and paucity of specialists call for greater exchanges with regard to research and development. Since 2017, at least five seminars or training courses have been held in Suzhou, Shanghai, Nanjing, Guangzhou, and Huzhou; they have involved universities (e.g., Nanjing Technical University), research institutes (e.g., Guangzhou Lingnan Architectural Conservation Institute), and international research and training institutes (e.g., WHITRAP-Suzhou).

\section{Closing Remarks}

The case studies presented here offer an understanding of the properties of existing structures; they have indicated suitable materials for conservation, which has to be conducted in terms of a carefully considered strategy for the buildings' rehabilitation or even conversion. Such a strategy has to involve such aspects as resource availability and environmental protection. 

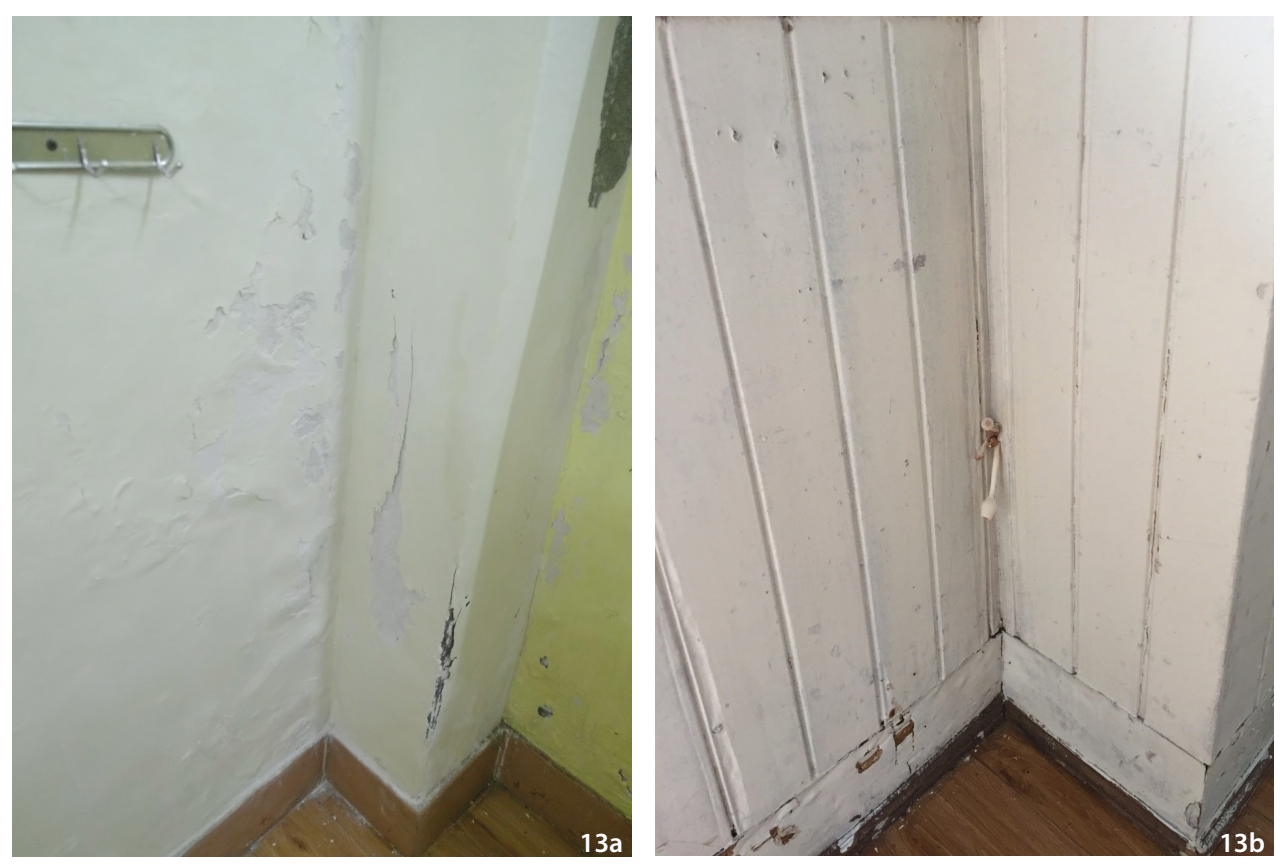

Figure 13 Defects in one kindergarten in Hangzhou, which may cause severe health risks, need a special solution (Source: the author).

Long-term monitoring with the German case studies demonstrated that sometimes the only solution for quality conservation of a structure may be to change its appearance. That could amount to modifying a façade from an un-rendered to a rendered surface or vice versa.

Certain weak types of natural stone, such as varieties of tuff, or weak brick require an outer layer of plaster to provide protection from weathering. The case studies presented in this paper show that even over 20 years following conservation, the measures employed are still functioning well. It has even been the case that conservation measures can result in aesthetic improvement, such as with revealing stone masonry. In the case of Spieskappel, it was possible to create the 'window to history', which was the small area without plaster that allowed a view of the underlying masonry. With conserved buildings, it is possible to monitor the condition of the stone. In the case of large façades, a lively impact can be created using coloured aggregates, plaster structures, or different architectural orders.

In the conservation and modernisation of the architectural heritage, thermal insulation is sometimes based on the use of natural materials. Accordingly, with the fürstliches Beamtenhaus in Usingen, a lime thermal insulation plaster with a natural light aggregate was applied to both the interior and exterior. With half-timbered houses in Germany, reed insulation combined with clay and lime plasters is the current approach to restoration. With the Lottehaus in Wetzlar-a museum used for storing papers related to Goethe-a mixture of modern and traditional materials, including lime and clay plasters, was employed in the restoration. In that way, an appropriate interior environment could be effected.

In the light of previous experience and joint examinations, we may conclude that it is necessary to make further efforts to increase and transfer knowledge related to restoration. In that way, the experience developed in Germany could be passed on to China. Moreover, knowledge related to local traditions and climatic conditions in China could be used to enrich the large field of built heritage conservation as a whole.

With further engagement, conservators, architects, building material manufacturers, and contractors should be able to enrich their knowledge regarding the selection and application of new and traditional materials. Specific applications of different plaster types can achieve the desired properties regarding moisture regulation and energy efficiency, thereby contributing to conservation and revaluation of the built heritage.

\section{Acknowledgments}

This research was conducted with the financial and administrative support of NSFC-Grant No. 51738008 and the Elite Innovation Program (2015) of Huzhou Municipal Government, Zhejiang Province, China. Thanks go to Professor Shibing Dai, College of Architecture and Urban Planning (CAUP), Tongji University, Shanghai for providing the opportunity to participate in recent research projects. 


\section{References}

Dai, Shibing, and Gesa Schwantes. 2016. "Conservation of Built Heritage in China-with Focus on Material Conservation." Paper presented at the conference of Bauinstandsetzen und Bauphysik - gestern - heute morgen, April, 27. Hrsg: Hans-Peter Leimer.

Dai, Shibing. 2018. "Preliminary Study on Wind Slaked Lime Used Before Qing Dynasty in China." Journal of Architectural Conservation 24 (2): 91-104.

Dettmering, Tanja, and Helmut Kollmann. 2011. Putze in Bausanierung und Denkmalpflege [Plasters in Building Renovation and Historic Preservation]. Berlin: Beuth Praxis,.

Dettmering, Tanja. 1997. "Mineralogische und technologische Eigenschaften von hydraulischem Kalk als Bindemittel von Restaurierungsmörteln für Baudenkmäler aus Naturstein. " [Mineralogical and Technological Properties of Hydraulic Lime as a Binder of Restoration Mortars for Monuments of Natural Stone]. Dissertation., Universität Gießen.

Dettmering, Tanja. Forthcoming. Historical Plasters in Connection with Thermal Insulations. Elsevier Verlag.

DIN (Deutsches Institut für Normung). 2018. DIN 185501 (Januar 2018, Ersatz für Ausgabe 2014-12) und DIN 18550-2 (Januar 2018, Ersatz für Ausgabe 2015-06), Ergänzende Festlegungen zu DIN EN 13914-1 für Außenputze und ergänzende Festlegungen zu DIN EN 13914-2 für Innenputze, Entwurf 2017-03.

IFS (Institut für Steinkonservierung), ed. 2003. Umweltbedingte Gebäudeschäden an Denkmälern durch die Verwendung von Dolomitkalkmörteln [Environmental Damage to Monuments through the Use of Dolomite Lime Mortar]. Mainz: Institut für Steinkonservierung.

Quietmeyer, Friedrich. 1911. Zur Geschichte der Erfindung des Portlandzements [On the History of the Invention of Portland Cement]. Berlin:Toningustrie-Zeitung, G.m.b.H.

Rauschenbach, F. 1994. “Organische Mörtel-Zusätze.” [Organic Mortar Accessories]. Putz-Stuck-Trockenbau 47 (10): 14-18.

Trommer, Sven. 2016. Dokumentation über die restauratorische Voruntersuchung, Befunderhebung, Fassade und Innenräume des Objekts Fürstliches Beamtenhaus [Documentation about the Restoration Preliminary Examination, Evaluation, Façade and Interiors of the Object Princely Civil Servants House]. Usingen: Weilburg.

Vitruvius Pollio, Marcus. (Circa 25 BC) 1987. De architectura libri decem [Ten Books on Architecture].
Translated by August Rode. Reprint, Zurich and Munich: Artemis Publishing.

Worch, Anatol. 2016. "Innendämmung - Eine vielfach verkannte Geschichte." [Interior Insulation-A Historically Misunderstood Story]. Paper presented at the conference of Bauinstandsetzen und Bauphysik gestern - heute - morgen, April, 27. Hrsg: Hans-Peter Leimer.

WTA. 2002. WTA-Merkblatt 2-7-01/D Kalkputze in der Denkmalpflege [Lime-based Plaster for Architectural Heritage]. Fraunhofer: IRB Verlag.

WTA. 2006. WTA-Merkblatt 2-10-06/D, Opferputze [Sacrificial Plasters]. Fraunhofer: IRB Verlag.

WTA. 2018. WTA-Merkblatt E-4-9 Instandsetzen von Gebäude- und Bauteilsockeln [Sealing of Structural Building Elements in Contact with Soil]. Fraunhofer: IRB Verlag. 